JURNAL RISET MAHASISWA AKUNTANSI (JRMA)

Volume 8, No. 1, Tahun 2020

e-ISSN : 2715 - 7016

\title{
PENGARUH GOOD GOVERNANCE, SISTEM PENGENDALIAN INTERN PEMERINTAH, KOMPETENSI SUMBER DAYA MANUSIA TERHADAP KUALITAS LAPORAN KEUANGAN PEMERINTAH DAERAH (LKPD) PADA OPD KOTA MALANG
}

\author{
Vika Erinna AgustiningTyas \\ Email : vickaerinna5@gmail.com \\ Irma Tyasari \\ Doni Wirshandono Yogivaria \\ Program Studi Akuntansi, Fakultas Ekonomika dan Bisnis Universitas Kanjuruhan Malang
}

\begin{abstract}
ABSTRAK
Penelitian ini bertujuan untuk menguji dan menjelaskan pengaruh good governance, sistem pengendalian intern pemerintah dan kompetensi sumber daya manusia terhadap kualitas laporan keuangan pemerintah daerah (LKPD) pada Organisasi Perangkat Daerah (OPD) Kota Malang. Penelitian kuantitatif ini menentukan sampel dengan purposive sampling dengan kriteria responden di 28 OPD Kota Malang pada Sub. Bagian Perencanaan dan Keuangan sejumlah 146 responden. Jenis data yang digunakan adalah menggunakan data primer. Teknik pengumpulan data dari kuesioner dan studi pustaka. Hasil penelitian menunjukan bahwa good governance dan sistem pengendalian intern pemerintah berpengaruh signifikan positif terhadap kualitas laporan keuangan pemerintah daerah (LKPD) pada Organisasi Perangkat Daerah (OPD) Kota Malang. Sedangkan kompetensi sumber daya manusia tidak berpengaruh secara signifikan terhadap kualitas laporan keuangan pemerintah daerah (LKPD) pada Organisasi Perangkat Daerah Kota Malang. Implikasi penelitian ini dapat mengukur aspek-aspek apa saja yang menjadi prioritas penulis dalam mengungkapkan kualitas laporan keuangan di Pemerintah Kota Malang

Kata Kunci : Good Governance, Sistem Pengendalian Intern Pemerintah, Kompetensi Sumber Daya Manusia dan Kualitas Laporan Keuangan Pemerintah Daerah.
\end{abstract}

\begin{abstract}
This study aims to examine and explain the effect of good governance, government internal control systems and human resource competencies on the quality of local government financial statements (LKPD) in Malang City Organization (OPD). This quantitative study determined the sample by purposive sampling with the criteria of respondents in 28 OPD Malang in Sub. The Planning and Financial Section is 146 respondents. The type of data used is primary data. Data collection techniques from questionnaires and literature study. The results showed that good governance and the government's internal control system had a significant positive effect on the quality of local government financial reports (LKPD) in Malang City's Organization (OPD). Whereas human resource competency does not significantly influence the quality of the financial statements of the local government (LKPD) in Malang City Regional Organization. The implications of this study can measure what aspects are the priorities of the author in expressing the quality of financial statements in the Government of Malang City

Keywords: Good Governance, Government Internal Control Systems, Human Resources Competence and Quality of Local Government Financial Reports.
\end{abstract}

Copyright $@$ JRMA 2020 e-ISSN. 2715-7016

Hal | 1 
Vika Erinna AgustiningTyas, Pengaruh Good Governance, Sistem Pengendalian Intern Pemerintah, Kompetensi Sumber Daya Manusia Terhadap Kualitas Laporan Keuangan Pemerintah Daerah (LKPD)

Pada OPD Kota Malang

\section{PENDAHULUAN}

Semakin berkembangnya tingkat intelektual masyarakat pada era globalisasi ini mendorong perangkat daerah untuk dapat menyelenggarakan suatu instansi pemerintahan yang baik dengan mempertanggungjawabkan pelaksanaan tujuan instansi tersebut. Peraturan Pemerintah No. 18 Tahun 2016 Tentang Perangkat Daerah menyatakan perangkat daerah Kabupaten atau Kota merupakan unsur pembantu Bupati atau Walikota dan DPRD Kabupaten atau Kota dalam menyelenggarakan urusan kepemerintahan daerah Kabupaten atau Kota. Salah satu bentuk pertanggungjawaban perangkat daerah dalam mengelola keuangan adalah dengan membuat laporan keuangan yang berkualitas sesuai peraturan yang berlaku dan laporan tersebut dapat diandalkan untuk disajikan kepada pihak yang berkepentingan. Fenomena mengenai keberhasilan Kota Malang 8x meraih Wajar Tanpa Pengecualian (WTP) atas Laporan Keuangan Pemerintah Daerah (LKPD) tahun anggaran 2018 dari Kementerian Keuangan Republik Indonesia (Merdeka.com, 2019). Secara substansi bahwa LKPD harus disajikan dalam bentuk pengolahan yang jujur dan efektif dan efisien untuk mencapai sasaran keadilan untuk seluruh masyarakat Kota Malang. Peraturan Pemerintah Nomor 12 tahun 2019 tentang Pengelolaan Keuangan Daerah akan menjadi referensi untuk perencanaan, proses menggunakan anggaran, proses monitoring, sampai akhirnya proses untuk menyusun laporan pertanggung jawaban. Dianugerahkannya opini WTP yang diterima Pemerintah Kota Malang tidak dapat langsung dikatakan bahwa pengelolaan keuangan sudah terlaksana benar dan transparan. Karena terbukti adanya indikasi masalah pada laporan audit BPK. Salah satu yang terbukti adalah mengenai anggaran Pemkot Malang dana sejumlah Rp. 538 miliar tak terserap saat pos perawatan jalan rusak dianggarkan kurang dari Rp. 2 miliar pada tahun 2019 (SuryaMalang.com 2019) dan mengenai 42 Anggota DPRD korupsi (JawaPos.com, 2018). Berdasarkan fenomena tersebut dapat disimpulkan bahwa untuk membuktikan penyajian laporan keuangan yang baik maka diperlukan suatu laporan keuangan yang berkualitas untuk mencegah terjadinya kecurangan fraud dan mengantisipasi adanya tindakan korupsi. Mahmudi (2019) Kualitas laporan keuangan disajikan untuk memberikan informasi kepada stakeholders dalam membuat keputusan sosial, politik, dan ekonomi sehingga keputusan yang diambil bisa lebih berkualitas.

Suatu laporan keuangan dapat dikatakan berkualitas apabila yang dihasilkan memenuhi karakteristik kualitatif pada suatu laporan keuangan sebagaimana disebutkan pada Peraturan Pemerintah Nomor 71 Tahun 2010 yaitu relevan, andal, dapat dibandingkan dan dapat dipahami. Salah satunya dengan menerapkan suatu tata kelola pemerintahan yang baik (good governance). Priansa (2018) mendefinisikan "Good Governance sebagai suatu sistem dan mekanisme yang mengatur pola hubungan antara pemerintah, dunia usaha/swasta, dan masyarakat dalam rangka penyelenggaraan pemerintahan yang bersih, demokratis, efektif, dan efisien sesuai dengan cita-cita terbentuknya masyarakat madani yang makmur, sejahtera, dan mandiri". Mengenai fenomena yang terjadi yaitu keberhasilan pemerintah Kota Malang dalam menerima penghargaan sebagai Top 99 Inovasi Pelayanan Publik 2019 yang diberikan oleh Kementrian Pendayagunaan Aparatur Negara dan Reformasi Birokrasi bahwa orientasi inovasi bukan sekedar menjembatani kehadiran program pemerintah, tetapi diharapkan mampu mengakomodir kebutuhan pada lingkungannya. Kecenderungan karakter, budaya, dan Daftar Nominatif Anggaran (DNA) milenial adalah pelayanan yang cepat, mudah dan aksesibilitas tinggi harus menggunakan anggaran secara efisien dan tepat sesuai prinsip good governance (MalangTimes.com, 2019).

Terdapat 9 prinsip good governance yang diadaptasi dari United Nations Development Programs (UNDP) dalam Priansa (2018) yaitu "Participation, rule of law, transparency, responsiveness, consensus orientation, equity, effeciency and effectiveness, accountability, strategic vision". Untuk menerapkan suatu tata kelola pemerintahan yang baik (good governance) maka diperlukan adanya 
Vika Erinna AgustiningTyas, Pengaruh Good Governance, Sistem Pengendalian Intern Pemerintah, Kompetensi Sumber Daya Manusia Terhadap Kualitas Laporan Keuangan Pemerintah Daerah (LKPD)

Pada OPD Kota Malang

sistem yang dapat mengatur dan mengawasi perangkat daerah Kota Malang yaitu sistem pengendalian intern pemerintah. Mahmudi (2019) Sistem pengendalian intern pemerintah merupakan suatu proses integral tindakan dan kegiatan manajemen dan jajarannya untuk memberikan keyakinan dalam mencapai tujuan organisasi melalui kegiatan yang efektif efisien, keandalan pelaporan keuangan dan ketaatan terhadap peraturan. Sebagai tolok ukur agar berjalannya sistem tata kelola pemerintah yang baik (good governance) dan sistem pengendalian internal pemerintah terhadap kualitas laporan keuangan perangkat daerah diperlukan adanya kompetensi sumber daya manusia. Mangkunegara (2012) mendefinisikan "Kompetensi sumber daya manusia adalah kompetensi yang berhubungan dengan pengetahuan, keterampilan, kemampuan dan karakteristik kepribadian yang mempengaruhi secara langsung terhadap kinerjanya". Penelitian sebelumnya diteliti Ni Made Mei (2018) mengenai faktor yang mempengaruhi kualitas LKPD pada OPD Kota Denpasar, hasilnya menunjukan good governance dan kompetensi sumber daya manusia berpengaruh terhadap kualitas laporan keuangan. Hasil penelitian ini selaras dengan penelitian yang dilakukan Rusvianto, Mulyani \& Yuliafitri (2018) menunjukan SPIP dan kompetensi SDM berpengaruh positif signifikan terhadap kualitas LKPD pada SKPD Kota Bandung. Hasil penelitian berbeda dilakukan oleh Wijayanti (2017) yang menyatakan kompetensi SDM tidak berpengaruh signifikan terhadap kualitas LKPD pada DPPKAD Kabupaten Sukoharjo. Sedangkan hasil penelitian yang diteliti oleh Ramadhani (2018) menyatakan bahwa SPIP, pemanfaatan teknologi informasi dan kompetensi staf tidak berpengaruh terhadap kualitas LKPD. Dan hasil penelitian Sari \& Fadli (2016) menyatakan good governance tidak berpengaruh terhadap kualitas LKPD Provinsi Bengkulu. Berdasarkan fenomena dan tinjauan teori mengenai hasil penelitian diatas maka peneliti termotivasi untuk menguji kembali variabel karena masih terdapat inkonsistensi pada hasil penelitian sebelumnya, penelitian ini menggabungkan variabel-variabel yang sebelumnya belum diuji secara bersamasama terhadap variabel kualitas laporan keuangan daerah. Maka judul yang diambil sebagai penelitian ini yaitu "Pengaruh good governance, sistem pengendalian intern pemerintah, dan kompetensi sumber daya manusia terhadap kualitas laporan keuangan pemerintah daerah pada OPD Kota Malang".

\section{KAJIAN PUSTAKA}

\section{Laporan Keuangan Pemerintah Daerah}

Peraturan Pemerintah Republik Indonesia Nomor 71 Tahun 2010 Tentang Standar Akuntansi Pemerintahan menyatakan "Laporan keuangan untuk tujuan umum adalah laporan untuk memenuhi kebutuhan para pengguna laporan keuangan. Laporan keuangan yang disajikan adalah dalam dokumen publik lain seperti laporan tahunan".

\section{Kualitas Laporan Keuangan}

Mahmudi (2019) "Kualitas laporan keuangan merupakan informasi untuk membantu stakeholders dalam membuat keputusan sehingga keputusan yang diambil bisa lebih berkualitas". Ada 5 indikator dalam kualitas informasi laporan keuangan yaitu : Relevan, Andal, Dapat Dibandingkan dan Dapat Dipahami

\section{Good Governance}

Priansa (2018) "Good Governance merupakan sistem dan mekanisme yang mengatur pola hubungan antara pemerintah, dunia usaha/swasta, dan masyarakat dalam rangka penyelenggaraan pemerintahan yang bersih, demokratis, efektif, dan efisien sesuai dengan cita cita terbentuknya masyarakat madani yang makmur, sejahtera, dan mandiri".

\section{Sistem Pengendalian Intern Pemerintah}

Peraturan Pemerintah Republik Indonesia Nomor 60 Tahun 2008 Tentang Sistem Pengendalian Intern Pemerintah merupakan suatu proses integral kegiatan pimpinan dan 
Vika Erinna AgustiningTyas, Pengaruh Good Governance, Sistem Pengendalian Intern Pemerintah, Kompetensi Sumber Daya Manusia Terhadap Kualitas Laporan Keuangan Pemerintah Daerah (LKPD)

Pada OPD Kota Malang

pegawai dalam memberikan keyakinan tujuan organisasi melalui kegiatan yang efektif, efisien dan ketaatan terhadap peraturan.

Kompetensi Sumber Daya Manusia

Mangkunegara (2012) "Kompetensi sumber daya manusia adalah kompetensi yang berhubungan dengan pengetahuan, keterampilan, kemampuan dan karakteristik kepribadian yang mempengaruhi terhadap kinerja".

\section{HIPOTESIS PENELITIAN}

1. H1 : Good governance, sistem pengendalian intern pemerintah, dan kompetensi sumber daya manusia

berpengaruh secara simultan terhadap kualitas laporan keuangan pemerintah daerah

2. H2 : Good governance berpengaruh terhadap kualitas laporan keuangan pemerintah daerah

3. H3 : Sistem pengendalian intern pemerintah berpengaruh terhadap kualitas laporan keuangan

pemerintah daerah

4. H4 : Kompetensi sumber daya manusia berpengaruh terhadap kualitas laporan keuangan pemerintah

daerah

\section{METODE PENELITIAN}

Jenis data yang digunakan yaitu data primer yang diperoleh secara langsung dari 28 Organisasi Perangkat Daerah Kota Malang melalui kuesioner. Teknik pengambilan sampel menggunakan metode Purposive sampling dengan kriteria responden pada Sub. Bagian Perencanaan \& Keuangan. Sampel yang digunakan dalam penelitian ini adalah sejumlah 146 sampel dari 13 Dinas, 1 Satpol PP, 5 Badan, 1 BPBD, 1 Inspektorat, 1 Sekretariat Daerah, 1 Sekretariat DPRD, 5 Kecamatan pada OPD Kota Malang.

\section{DEFINISI OPERASIONAL DAN PENGUKURAN VARIABEL}

\section{Kualitas Laporan Keuangan Pemerintah Daerah (Y)}

Kualitatif laporan keuangan merupakan suatu ukuran normatif yang perlu diwujudkan dalam informasi akuntansi sehingga dapat memenuhi tujuannya (Nordiawan \& Hertianti, 2010). Ada 4 indikator mengenai variabel Kualitas Laporan Keuangan Pemerintah Daerah yaitu relevan, andal, dapat dibandingkan dan dapat dipahami.

\section{Good Governance (X1)}

Priansa (2018) "Good Governance merupakan suatu sistem dan mekanisme yang mengatur pola hubungan antara pemerintah, dunia usaha/swasta, dan masyarakat dalam rangka penyelenggaraan pemerintahan yang bersih, demokratis, efektif, dan efisien sesuai cita-cita terbentuknya masyarakat madani yang makmur, sejahtera, dan mandiri". Ada 9 indikator yaitu participation, rule of law, transparency, responsiveness, consensus orientation, equity, effeciency and effectiveness, accountability, strategic vision.

\section{Sistem Pengendalian Intern Pemerintah (X2)}

PP No. 60 Tahun 2008 Tentang Sistem Pengendalian Intern Pemerintah adalah kegiatan untuk memberikan keyakinan tujuan organisasi melalui kegiatan yang efektif dan efisien, keandalan pelaporan keuangan, dan ketaatan terhadap peraturan perundang-undangan yang berlaku dan diselenggarakan secara menyeluruh di lingkungan pemerintah pusat maupun pemerintah daerah. Terdapat 5 indikator yaitu lingkungan pengendalian, penilaian risiko, informasi\&komunikasi, pemantauan, kegiatan pengendalian. 
Vika Erinna AgustiningTyas, Pengaruh Good Governance, Sistem Pengendalian Intern Pemerintah, Kompetensi Sumber Daya Manusia Terhadap Kualitas Laporan Keuangan Pemerintah Daerah (LKPD)

Pada OPD Kota Malang

\section{Kompetensi Sumber Daya Manusia (X3)}

Mangkunegara (2012) mendefinisikan "Kompetensi sumber daya manusia adalah kompetensi yang berhubungan dengan pengetahuan, keterampilan, kemampuan dan karakteristik kepribadian yang mempengaruhi secara langsung terhadap kinerjanya". Terdapat 3 indikator mengenai variabel kompetensi sumber daya manusia yaitu Keterampilan, Pengetahuan, dan Sikap/Perilaku.

\section{TEKNIK ANALISIS DATA}

\section{Statistik Deskriptif}

Statistik deskriptif yaitu hal yang berhubungan dengan pengumpulan data, penyamplingan, peringkasan data dan penyajian hasil peringkasan. Pengukuran statistik deskriptif bertujuan untuk mendeskripsikan secara angka statistik pada variabel yang digunakan didalam penelitian ini. Ukuran yang akan dipakai dalam penelitian ini adalah nilai rata-rata, nilai maksimum, nilai minimum, dan deviasi standard.

\section{Uji Validitas}

Ghozali (2016) Uji validitas merupakan uji yang berkaitan dengan permasalahan instrument yang digunakan untuk mengukur variabel tersebut dapat mengukur secara tepat sesuatu yang akan diukur. Apabila instrument yang digunakan valid, maka instrument tersebut dapat mengukur feomena yang diteliti secara tepat. Pengujian validitas dapat menggunakan Pearson Correlation dengan cara menguji korelasi antara skor masing masing butir pertanyaan yang digunakan dengan total skor.

\section{Uji Reliabilitas}

Ghozali (2016) Reliabilitas adalah alat untuk mengukur suatu kuesioner yang merupakan indikator dari variabel. Kuesioner dapat dikatakan reliabel apabila jawaban seseorang terhadap pernyataan adalah konsisten atau stabil dari waktu ke waktu. Ada beberapa metode pengujian reliabilitas yang dapat digunakan seperti Alpha Croncbach adalah apabila nilai Alpha $>0.06$ maka dapat dinyatakan instrument reliabel

\section{Uji Asumsi Klasik}

Uji asumsi klasik digunakan untuk menguji kualitas data sehingga diketahui keabsahannya dan menghindari terjadinya estimasi bias. Uji asumsi klasik adalah tahap awal yang digunakan sebelum analisis regresi berganda bertujuan untuk mengetahui model regresi apakah menunjukkan hubungan signifikan.

\section{Uji Normalitas}

Ghozali (2016), uji normalitas merupakan pengujian yang digunakan untuk menguji apakah dalam model regresi, variabel independen dan dependenya memiliki kontribusi normal atau tidak. Terdapat dua cara untuk mendeteksi apakah residual berdistribusi normal atau tidak, yaitu dengan menggunakan analisis grafik dan analisis statistik. Untuk menguji data berdistribusi normal atau tidak dilakukan uji statistik Kolmogorov-Smirnov Test. Residual berdistribusi normal jika memiliki nilai signifikansi $>0,05$ atau $5 \%$. Analisis Statistik Parametrik harus memenuhi asumsi data yang terdistribusi normal, sehingga perlu dilakukan pengujian Normalitas Data. Pengujian yang sering digunakan adalah metode grafik (Normal Probabiliti Plot), apabila sebaran data pada grafik berada di sekitar garis diagonal berarti data berdistribusi normal.

\section{Uji Multikolinearitas}

Ghozali (2016), Uji Multikolinearitas dilakukan untuk mengetahui apakah terdapat korelasi atau hubungan yang kuat antara variabel-varibel independen dalam model persamaan regresi. Model regresi yang baik sebaiknya tidak terjadi korelasi antara variabel bebas. Mendeteksi ada tidak multikorelasi yaitu dengan melihat Tolerance Value dan Variance Inflation 
Vika Erinna AgustiningTyas, Pengaruh Good Governance, Sistem Pengendalian Intern Pemerintah, Kompetensi Sumber Daya Manusia Terhadap Kualitas Laporan Keuangan Pemerintah Daerah (LKPD)

Pada OPD Kota Malang

Factor (VIF). Sebagai acuan dapat disimpulkan apabila nilai tolerance $<0.10$ dari nilai VIF $>10$, maka tidak ada multikolinieritas antar variabel bebas dalam model regresi.

\section{Uji Heteroskedastisitas}

Ghozali (2016) Uji heteroskedastisitas bertujuan untuk menguji apakah dalam regresi terjadi kesamaan varian dari residu suatu pengantaran ke pengamatan lain maka disebut homoskedastisitas dan apabila varian residual suatu pengamatan ke pengamatan lain berbeda maka disebut heteroskedasitas. Uji heteroskedastisitas dapat dilakukan dengan cara uji glejser, dasar untuk mengambil keputusan uji statistik dengan mengggunakan metode uji glejser yaitu dengan tingkat signifikan diatas $\alpha=0,05$ maka disimpulkan tidak terjadi heteroskedastisitas. Namun, bila tingkat signifikasi dibawah $\alpha=0,05$ maka ada gejala heteroskedastisitas.

\section{Analisis Regresi Linear Berganda}

Pada penelitian ini variabel independennya berjumlah tiga dan variabel dependen berjumlah satu. Analisis regresi untuk menguji ada atau tidaknya pengaruh variabel bebas terhadap variabel terikat. Persamaan regresi berganda adalah :

\section{Pengujian Hipotesis}

$$
\mathrm{Y}=\alpha+\beta 1 . X_{1}+\beta 2 . X_{2}+\beta 3 . X_{3}+\mathrm{e}
$$

Pengujian hipotesis pertama, kedua, dan ketiga dilakukan dengan pengujian variable secara simultan (Uji F) dan pengujian variabel secara parsial (Uji T). Untuk mengetahui besarnya pengaruh variabel independen dapat menjelaskan variabel dependen dapat dijelaskan dengan menggunakan koefisien determinan $\left(R^{2}\right)$. Ketiga pengujian tersebut akan dijelaskan sebagai berikut :

\section{Uji F (Uji Simultan)}

Digunakan untuk menguji seberapa besar variabel good governance, sistem pengendalian internal pemerintah, kompetensi sumber daya manusia secara bersama-sama berpengaruh terhadap kualitas laporan keuangan pemerintah daerah (LKPD).

\section{Uji t (Uji Parsial)}

Yaitu suatu analisis untuk mengetahui seberapa besar Pengaruh good governance, sistem pengendalian intern pemerintah, kompetensi sumber daya manusia terhadap kualitas laporan keuangan pemerintah daerah (LKPD).

\section{Koefisien Determinasi (Adjusted $R$ )}

Koefisien determinan $\left(R^{2}\right)$ untuk menunjukkan persentase semua pengaruh variabel good governance, sistem pengendalian internal pemerintah, dan kompetensi sumber daya manusia terhadap variabel kualitas LKPD. Persentase tersebut dapat menunjukkan seberapa besar variabel bebas dapat menjelaskan variabel terikat.

\section{HASIL DAN PEMBAHASAN}

\section{Hasil Uji Validitas dan Reliabilitas}

Dapat diketahui bahwa butir-butir pertanyaan yang digunakan dalam penelitian ini valid, dan tidak ada beberapa butir pertanyaan yang tidak valid. Kriteria bahwa butir pertanyaan tersebut dapat dikatakan valid apabila nilai signifikansi koefisien korelasi $<\operatorname{taraf} \alpha$ (yaitu sebesar $0.05)$.

\section{Hasil Uji Reliabilitas}

Hasil uji reliabilitas dengan metode Alpha Croncbach, diperoleh nilai Alpha dari variabel yang telah diuji memiliki hasil lebih dari 0,6. Kriteria suatu instrument penelitian dinyatakan reliabel apabila nilai Alpha $>0,6$, jadi pada hasil uji reliabilitas tersebut terdapat 4 variabel pada tiap butir-butir kuesioner yang menyatakan reliabel. Inti dari pengujian reliabel yakni apakah 
Vika Erinna AgustiningTyas, Pengaruh Good Governance, Sistem Pengendalian Intern Pemerintah, Kompetensi Sumber Daya Manusia Terhadap Kualitas Laporan Keuangan Pemerintah Daerah (LKPD)

Pada OPD Kota Malang

butir-butir pertanyaan yang digunakan dalam penelitian ini reliabel atau masih dapat digunakan untuk penelitian selanjutnya (Ghozali, 2018)

Hasil Uji Statistik Deskriptif

Hasil Uji Statistik Deskriptif Variabel Penelitian

Descriptive Statistics

\begin{tabular}{|l|c|r|r|r|r|}
\hline & $\mathrm{N}$ & Minimum & Maximum & Mean & Std. Deviation \\
\hline Good.Governance & 146 & 32 & 84 & 74.59 & 7.296 \\
SPIP & 146 & 26 & 86 & 77.10 & 8.938 \\
Kompetensi.SDM & 146 & 15 & 30 & 24.55 & 2.747 \\
Kualitas.LKPD & 146 & 16 & 40 & 33.58 & 3.456 \\
Valid N (listwise) & 146 & & & & \\
\hline
\end{tabular}

Variabel Good Governance memiliki nilai rata-rata sebesar 74,59 ini menunjukkan bahwa sebagian besar responden cenderung menjawab tidak setuju untuk pertanyaan yang diajukan berkaitan dengan masalah Good Governance. Nilai minimum variabel dimensi Good Governance adalah sebesar 32 yang artinya adalah terdapat responden yang menjawab sangat tidak setuju. Sementara itu nilai maksimum variabel Good Governance adalah sebesar 84 yang menunjukkan bahwa terdapat responden yang cenderung menjawab sangat setuju.

Variabel Sistem Pengendalian Internal Pemerintah (SPIP) memiliki nilai rata-rata sebesar 77,10 ini menunjukkan bahwa sebagian besar responden cenderung menjawab tidak setuju untuk pertanyaan yang diajukan berkaitan dengan masalah Sistem Pengendalian Internal Pemerintah (SPIP). Nilai minimum variabel Sistem Pengendalian Internal Pemerintah (SPIP) adalah sebesar 26 yang artinya adalah terdapat responden yang menjawab sangat tidak setuju. Sementara itu nilai maksimum variabel Sistem Pengendalian Internal Pemerintah (SPIP) adalah sebesar 86 yang menunjukkan bahwa terdapat responden yang cenderung menjawab sangat setuju.

Variabel Kompetensi Sumber Daya Manusia memiliki nilai rata-rata sebesar 24,55 ini menunjukkan bahwa sebagian besar responden cenderung menjawab tidak setuju untuk pertanyaan yang diajukan berkaitan dengan masalah Kompetensi Sumber Daya Manusia. Nilai minimum variabel Kompetensi Sumber Daya Manusia adalah sebesar 15 yang artinya adalah terdapat responden yang menjawab sangat tidak setuju. Sementara itu nilai maksimum variabel Kompetensi Sumber Daya Manusia adalah sebesar 30 yang menunjukkan bahwa terdapat responden yang cenderung menjawab sangat setuju.

Variabel Kualitas Laporan Keuangan Pemerintah Daerah (LKPD) memiliki nilai rata-rata sebesar 33,58 ini menunjukkan bahwa sebagian besar responden cenderung menjawab tidak setuju untuk pertanyaan yang diajukan berkaitan dengan masalah Kualitas Laporan Keuangan Pemerintah Daerah (LKPD). Nilai minimum variabel Kualitas Laporan Keuangan Pemerintah Daerah (LKPD) adalah sebesar 16 yang artinya adalah terdapat responden yang menjawab sangat tidak setuju. Sementara itu nilai maksimum variabel Kualitas Laporan Keuangan Pemerintah Daerah (LKPD) adalah sebesar 40 yang menunjukkan bahwa terdapat responden yang cenderung menjawab sangat setuju. 
Vika Erinna AgustiningTyas, Pengaruh Good Governance, Sistem Pengendalian Intern Pemerintah, Kompetensi Sumber Daya Manusia Terhadap Kualitas Laporan Keuangan Pemerintah Daerah (LKPD)

Pada OPD Kota Malang

\section{Hasil Uji Asumsi Klasik}

\section{Uji Normalitas}

Hasil Uji Kolmogorov-Smirnov

One-Sample Kolmogorov-Smirnov Test

\begin{tabular}{|c|c|c|}
\hline & & Unstandardized Residual \\
\hline $\mathrm{N}$ & & 146 \\
\hline Normal Parameters ${ }^{\mathrm{a}, \mathrm{b}}$ & Mean & .0000000 \\
\hline & Std. Deviation & 2.97614552 \\
\hline Most Extreme Differences & Absolute & .058 \\
\hline & Positive & .058 \\
\hline & Negative & -.055 \\
\hline Test Statistic & & .058 \\
\hline Asymp. Sig. (2-tailed) & & $.200^{\mathrm{c}, \mathrm{d}}$ \\
\hline
\end{tabular}

Hasil pengujian tersebut diperoleh Kolmogorov-Smirnov $Z$ sebesar 0,058 dengan nilai signifikansi (Asymp. Sig 2-tailed) sebesar 0,200 $>\alpha=0,05$ berarti tidak signifikan maka dinyatakan nilai residual tersebut berdistribusi normal.

\section{Uji Multikolinieritas}

\section{Hasil Uji Multikolinieritas}

\begin{tabular}{|c|c|c|c|c|c|c|c|}
\hline \multirow[b]{3}{*}{ Model } & \multicolumn{3}{|c|}{ Coefficients $^{\mathrm{a}}$} & \multirow[b]{3}{*}{$\mathrm{t}$} & \multirow[b]{3}{*}{ Sig. } & & \\
\hline & \multicolumn{2}{|c|}{$\begin{array}{c}\text { Unstandardized } \\
\text { Coefficients }\end{array}$} & $\begin{array}{c}\text { Standardized } \\
\text { Coefficients }\end{array}$ & & & \multicolumn{2}{|c|}{$\begin{array}{c}\text { Collinearity } \\
\text { Statistics }\end{array}$} \\
\hline & B & Std. Error & Beta & & & Tolerance & VIF \\
\hline 1 (Constant) & 14.289 & 3.485 & & 4.101 & .000 & & \\
\hline Good.Governance & .138 & .041 & .292 & 3.398 & .001 & .707 & 1.414 \\
\hline SPIP & .111 & .033 & .287 & 3.340 & .001 & .708 & 1.412 \\
\hline Kompetensi.SDM & .017 & .091 & .014 & .192 & .848 & .997 & 1.003 \\
\hline
\end{tabular}

a. Dependent Variable: Kualitas.LKPD

Hasil perhitungan nilai tolerance menunjukkan tidak ada variabel independen yang memiliki nilai tolerance kurang dari 0.10 yang berarti tidak ada korelasi antar variabel independen. Nilai VIF pada kolom Collinearity Statistic, untuk semua variabel independen yang memiliki nilai lebih dari 10. Hasil tersebut tidak terjadi multikolinieritas antar variabel.

\section{Uji Heteroskedastisitas}

Hasil Uji Glejser

Coefficients ${ }^{a}$

\begin{tabular}{|c|c|c|c|c|c|c|}
\hline \multirow[b]{2}{*}{ Model } & \multicolumn{2}{|c|}{ Unstandardized Coefficients } & \multirow{2}{*}{\multicolumn{2}{|c|}{$\begin{array}{c}\text { Standardized Coefficients } \\
\text { Beta }\end{array}$}} & \multirow[b]{2}{*}{$\mathrm{t}$} & \multirow[b]{2}{*}{ Sig. } \\
\hline & $\mathrm{B}$ & Std. Error & & & & \\
\hline 1 (Constant) & 4.077 & 1.877 & & & 2.172 & .032 \\
\hline Good.Governance & .001 & .022 & & .004 & .036 & .972 \\
\hline SPIP & .007 & .018 & & .041 & .416 & .678 \\
\hline Kompetensi.SDM & -.091 & .049 & & -.153 & -1.846 & .067 \\
\hline
\end{tabular}

a. Dependent Variable: Absres

Nilai signifikan antara pengaruh Good Governance terhadap Kualitas Laporan Keuangan Pemerintah Daerah (LKPD) sebesar 0,972 dimana 0,972 >0,05. Terdapat nilai signifikan antara Sistem Pengendalian Internal Pemerintah (SPIP) dengan Kualitas Laporan Keuangan Pemerintah Daerah (LKPD) sebesar 0,678 dimana 0,678 >0,05. Nilai signifikan antara Kompetensi Sumber Daya Manusia dengan Kualitas Laporan Keuangan Pemerintah Daerah (LKPD) sebesar 0,067 dimana 0,067 >0,05. Kesimpulannya tidak terjadi adanya heteroskedastisitas. 
Vika Erinna AgustiningTyas, Pengaruh Good Governance, Sistem Pengendalian Intern Pemerintah, Kompetensi Sumber Daya Manusia Terhadap Kualitas Laporan Keuangan Pemerintah Daerah (LKPD)

Pada OPD Kota Malang

\section{Hasil Uji Hipotesis}

1. Uji Regresi Linier Berganda

\section{Hasil Uji Regresi Linier Berganda}

\section{Coefficients $^{\mathrm{a}}$}

\begin{tabular}{|c|c|c|c|c|c|c|c|c|c|c|}
\hline \multirow[b]{2}{*}{ Model } & \multicolumn{2}{|c|}{$\begin{array}{l}\text { Unstandardize } \\
\text { d Coefficients }\end{array}$} & $\begin{array}{l}\text { Standardize } \\
\mathrm{d} \\
\text { Coefficients }\end{array}$ & \multirow[b]{2}{*}{$\mathrm{t}$} & \multirow[b]{2}{*}{ Sig. } & \multicolumn{3}{|c|}{ Correlations } & \multicolumn{2}{|c|}{$\begin{array}{l}\text { Collinearity } \\
\text { Statistics }\end{array}$} \\
\hline & B & $\begin{array}{l}\text { Std. } \\
\text { Error }\end{array}$ & Beta & & & $\begin{array}{c}\text { orde } \\
\mathrm{r}\end{array}$ & $\begin{array}{c}\text { Partia } \\
1\end{array}$ & Part & $\begin{array}{c}\text { Toleranc } \\
\text { e }\end{array}$ & VIF \\
\hline 1 (Constant) & $\begin{array}{r}14.28 \\
9\end{array}$ & 3.485 & & $\begin{array}{r}4.10 \\
1\end{array}$ & $\begin{array}{r}.00 \\
0\end{array}$ & & & & & \\
\hline $\begin{array}{l}\text { Good.Governan } \\
\text { ce }\end{array}$ & .138 & .041 & 292 & $\begin{array}{r}3.39 \\
8\end{array}$ & $\begin{array}{r}.00 \\
1\end{array}$ & .447 & .274 & $\begin{array}{r}.24 \\
6\end{array}$ & .707 & $\begin{array}{r}1.41 \\
4\end{array}$ \\
\hline SPIP & .111 & .033 & .287 & $\begin{array}{r}3.34 \\
0\end{array}$ & $\begin{array}{r}.00 \\
1\end{array}$ & .444 & .270 & $\begin{array}{r}.24 \\
1\end{array}$ & .708 & $\begin{array}{r}1.41 \\
2\end{array}$ \\
\hline $\begin{array}{l}\text { Kompetensi.SD } \\
\text { M }\end{array}$ & .017 & .091 & .014 & .192 & $\begin{array}{r}.84 \\
8\end{array}$ & .022 & .016 & $\begin{array}{r}.01 \\
4\end{array}$ & .997 & $\begin{array}{r}1.00 \\
3\end{array}$ \\
\hline
\end{tabular}

a. Dependent Variable: Kualitas.LKPD

Dibuat persamaan regresi linier berganda sebagai berikut :

$$
\begin{aligned}
& \mathrm{Y}=\alpha+\beta_{1} \mathrm{X}_{1}+\beta_{1} \mathrm{X}_{2}+\beta_{1} \mathrm{X}_{3}+\mathrm{e} \\
& \mathrm{Y}=14.289+0,138 \mathrm{X} 1+0,111 \mathrm{X} 2+0,017 \mathrm{X} 3+\mathrm{e}
\end{aligned}
$$

Pada hasil persamaan regresi tersebut, terlihat bahwa nilai konstanta adalah 44.222

1. Nilai konstanta sebesar 14.289 memiliki arti apabila variabel lainnya konstan, maka Kualitas Laporan Keuangan Pemerintah Daerah (LKPD) akan naik sebesar 14.289 satuan.

2. Nilai koefisien regresi Good Governance (X1) bernilai positif sebesar 0.138 memiliki arti apabila Good Governance meningkat sebesar 1 satuan dengan asumsi variabel lainnya konstan, maka Kualitas Laporan Keuangan Pemerintah Daerah (LKPD) akan meningkat sebesar 0.138 .

3. Nilai koefisien regresi Sistem Pengendalian Internal Pemerintah (X2) bernilai positif sebesar 0.111 memiliki arti apabila Sistem Pengendalian Internal Pemerintah meningkat sebesar 1 satuan dengan asumsi variabel lainnya konstan, maka Kualitas Laporan Keuangan Pemerintah Daerah (LKPD) akan meningkat sebesar 0.111 satuan.

4. Nilai koefisien regresi Kompetensi Sumber Daya Manusia (X3) bernilai positif sebesar 0.017 memiliki arti apabila Kompetensi Sumber Daya Manusia meningkat sebesar 1 satuan dengan asumsi variabel lainnya konstan, maka Kualitas Laporan Keuangan Pemerintah Daerah (LKPD) akan meningkat sebesar 0.017 satuan.

5. Error term (e) sebesar 3.485 yang artinya setiap peningkatan (penambahan) terhadap kualitas laporan keuangan pemerintah daerah (LKPD) selain dipengaruhi oleh variabel good governance, sistem pengendalian internal pemerintah (SPIP), dan kompetensi sumber daya manusia ternyata juga dipengaruhi oleh variabel lain yaitu sebesar 3.485. Variabel lain yang dimaksud adalah variabel lain yang belum dibahas dalam penelitian ini. 
Vika Erinna AgustiningTyas, Pengaruh Good Governance, Sistem Pengendalian Intern Pemerintah, Kompetensi Sumber Daya Manusia Terhadap Kualitas Laporan Keuangan Pemerintah Daerah (LKPD)

Pada OPD Kota Malang

\section{Uji Simultan (Uji Statistik f)}

\begin{tabular}{|c|c|c|c|c|c|}
\hline \multicolumn{6}{|c|}{$\begin{array}{l}\text { Hasil Uji Statistik F } \\
\text { ANOVA }^{\mathrm{a}}\end{array}$} \\
\hline Model & Sum of Squares & $\mathrm{df}$ & Mean Square & $\mathrm{F}$ & Sig. \\
\hline $\begin{array}{ll}1 & \text { Regression } \\
& \text { Residual } \\
& \text { Total }\end{array}$ & $\begin{array}{r}447.185 \\
1284.329 \\
1731.514\end{array}$ & $\begin{array}{r}3 \\
142 \\
145\end{array}$ & $\begin{array}{r}149.062 \\
9.045\end{array}$ & 16.481 & $.000^{\mathrm{b}}$ \\
\hline
\end{tabular}

Diketahui fhitung sebesar 16.481 Hasil uji signifikansi simultan menunjukkan bahwa signifikansi yaitu 0,000 $<0,05$ atau alpha $5 \%$. Ini berarti bahwa secara simultan variabel Good Governance (X1), Sistem Pengendalian Internal Pemerintah (X2), dan Kompetensi Sumber Daya Manusia (X3) berpengaruh signifikan terhadap Kualitas LKPD. Maka Ho ditolak (H1 diterima). Hasil penelitian ini menunjukkan bahwa dengan menyajikan kualitas LKPD dapat memberikan informasi kepada para pengguna laporan keuangan, penerapan good governance mendukung suatu tata kelola pemerintah yang baik untuk dapat meningkatkan kualitas pelayanan publik, sedangakan sistem pengendalian internal pemerintah yang baik dapat mencegah terjadinya fraud maupun hal buruk terkait keuangan organisasi dan tindak peyimpangan internal dan kompetensi sumber daya manusia yang berkompeten dapat mengerjakan suatu hal yang menjadi tanggungjawabnya sesuai dengan tugasnya dan tidak melanggar ketentuan yang berlaku.

\section{Uji Parsial (Uji Statistik t)}

Hasil Uji Statistik $\mathbf{t}$

Coefficients ${ }^{\mathrm{a}}$

\begin{tabular}{|c|c|c|c|c|c|}
\hline \multirow[b]{2}{*}{ Model } & \multicolumn{2}{|c|}{ Unstandardized Coefficients } & \multirow{2}{*}{$\frac{\text { Standardized Coefficient }}{\text { Beta }}$} & \multirow[b]{2}{*}{$\mathrm{t}$} & \multirow[b]{2}{*}{ Sig. } \\
\hline & $\mathrm{B}$ & Std. Error & & & \\
\hline 1 (Constant) & 14.289 & 3.485 & & 4.101 & .000 \\
\hline Good.Governance & .138 & .041 & .29 & 3.398 & .001 \\
\hline SPIP & .111 & .033 & .28 & 3.340 & .001 \\
\hline Kompetensi.SDM & .017 & .091 & .01 & .192 & .848 \\
\hline
\end{tabular}

a. Dependent Variable: Kualitas.LKPD

1. Pengaruh good governance terhadap kualitas laporan keuangan pemerintah daerah (LKPD)

Menunjukkan nilai thitung good governance sebesar $3.398<14.289$ dan sig 0.001 $<0.05$. Apabila nilai signifikansi kurang dari 0.05 ini berarti bahwa variabel good governance berpengaruh secara signifikan terhadap kualitas LKPD. Berdasarkan persamaan regresi terlihat bahwa koefisien variabel good governance adalah positif. Disimpulkan bahwa variabel good governance berpengaruh positif terhadap variabel kualitas LKPD artinya bahwa $\mathrm{H} 2$ diterima.

2. Pengaruh sistem pengendalian internal pemerintah (SPIP) terhadap kualitas laporan keuangan pemerintah daerah (LKPD)

Menunjukkan nilai t hitung SPIP sebesar $3.340<14.289$ dan sig $0.001<0.05$. Apabila nilai signifikansi kurang dari 0.05 ini berarti bahwa variabel SPIP berpengaruh secara signifikan terhadap kualitas LKPD. Sedangkan berdasarkan persamaan regresi terlihat bahwa koefisien variabel SPIP adalah positif. Maka dapat disimpulkan bahwa variabel SPIP berpengaruh positif terhadap variabel kualitas LKPD artinya bahwa H3 diterima. 
Vika Erinna AgustiningTyas, Pengaruh Good Governance, Sistem Pengendalian Intern Pemerintah, Kompetensi Sumber Daya Manusia Terhadap Kualitas Laporan Keuangan Pemerintah Daerah (LKPD)

Pada OPD Kota Malang

3. Pengaruh kompetensi sumber daya manusia terhadap kualitas laporan keuangan pemerintah daerah (LKPD)

Menunjukkan nilai t hitung kompetensi sumber daya manusia sebesar $0.192<$ 14.289 dan sig $0.848>0.05$. Apabila nilai signifikansi lebih besar dari 0.05 ini berarti bahwa variabel kompetensi sumber daya manusia tidak berpengaruh secara signifikan terhadap kualitas laporan keuangan pemerintah daerah (LKPD) artinya bahwa $\mathrm{H} 4$ ditolak.

4. Uji Koefisien Determinasi

Hasil Uji Koefisien Determinasi

Model Summary

\begin{tabular}{|l|c|r|r|r|}
\hline Model & R & R Square & Adjusted R Square & Std. Error of the Estimate \\
\hline 1 & $.508^{\mathrm{a}}$ & .258 & .243 & 3.007 \\
\hline
\end{tabular}

a. Predictors: (Constant), Kompetensi.SDM, SPIP, Good.Governance

b. Dependent Variable: Kualitas.LKPD

Nilai koefisien korelasi (R) menunjukkan hubungan antara variabel bebas Good Governance, SPIP, dan Kompetensi SDM dengan variabel terikat Kualitas LKPD sebesar 0.508 (50.8\%) Hal ini menunjukkan adanya hubungan antara variabel independen dengan variabel dependen. Sedangkan nilai R Square atau koefisien determinan sebesar 0.258 yang berarti bahwa pengaruh variabel dependen mampu dijelaskan oleh variabel independen sebesar $25.8 \%$. Sedangkan sisanya sebesar 0,742 atau $74.2 \%$ dijelaskan oleh faktor lain yang tidak disertakan dalam penelitian ini.

\section{PEMBAHASAN}

1. Pengaruh Good Governance, Sistem Pengendalian Internal Pemerintah (SPIP), Kompetensi Sumber Daya Manusia terhadap Kualitas Laporan Keuangan Pemerintah Daerah (LKPD)

Hasil pengujian dengan regresi linier berganda secara simultan menunjukkan bahwa good governance, SPIP, kompetensi SDM berpengaruh signifikan terhadap kualitas LKPD.

2. Pengaruh Good Governance terhadap Kualitas Laporan Keuangan Pemerintah Daerah (LKPD)

Penelitian ini menghasilkan hasil uji mengenai pengaruh good governance terhadap kualitas LKPD pada OPD Kota Malang. Adapun hasil pengujian secara parsial menunjukkan bahwa good governance berpengaruh signifikan positif terhadap kualitas LKPD. Hasil ini sejalan dengan penelitian Ni Made Mei (2018) yang menyatakan bahwa good governance berpengaruh terhadap kualitas LKPD. Diperkuat dengan penelitian oleh Karlina Ghazalah (2016) dimana good governance berpengaruh terhadap kualitas informasi laporan keuangan.

3. Pengaruh Sistem Pengendalian Internal Pemerintah (SPIP) terhadap Kualitas Laporan Keuangan Pemerintah Daerah (LKPD)

Penelitian ini menghasilkan hasil uji mengenai pengaruh SPIP pada OPD Kota Malang. Adapun hasil pengujian secara parsial menunjukkan bahwa SPIP berpengaruh signifikan positif terhadap kualitas LKPD Hasil penelitian ini juga sejalan dengan penelitian sebelumnya yang telah dilakukan oleh Dimas, Sri dan Indri (2018) yang menyatakan SPIP berpengaruh terhadap kualitas LKPD. Diperkuat dengan penelitian Lilis Wijayanti (2017), Triyanti (2017), Karlina Ghazalah (2016), Muhamad dan Furry (2018), Liani dan Kusmuriyanto (2017) dimana SPIP berpengaruh terhadap LKPD.

4. Pengaruh Kompetensi Sumber Daya Manusia terhadap Kualitas Laporan Keuangan Pemerintah Daerah (LKPD)

Penelitian ini menghasilkan hasil uji mengenai pengaruh kompetensi sumber daya manusia terhadap kualitas LKPD di OPD Kota Malang. Adapun hasil pengujian secara parsial 
Vika Erinna AgustiningTyas, Pengaruh Good Governance, Sistem Pengendalian Intern Pemerintah, Kompetensi Sumber Daya Manusia Terhadap Kualitas Laporan Keuangan Pemerintah Daerah (LKPD)

Pada OPD Kota Malang

menunjukkan bahwa kompetensi sumber daya manusia tidak berpengaruh secara signifikan terhadap kualitas LKPD. Hasil penelitian ini sejalan dengan penelitian sebelumnya yang telah dilakukan oleh Lilis Wijayanti (2017) yang menyatakan kompetensi sumber daya manusia tidak berpengaruh terhadap kualitas laporan keuangan pemerintah daerah secara statistik signifikan. Diperkuat dengan penelitian Liani dan Kusmuriyanto (2017) yang menyatakan kompetensi sumber daya manusia berpengaruh tidak signifikan terhadap kualitas laporan keuangan.

Kesimpulan

Berdasarkan pengujian dan penjelasan yang telah dilakukan, dapat disimpulkan bahwa secara simultan variabel good governance, sistem pengendalian internal pemerintah (SPIP), kompetensi sumber daya manusia berpengaruh signifikan terhadap kualitas laporan keuangan pemerintah daerah OPD Kota Malang. Secara parsial good governance dan sistem pengendalian intern pemerintah berpengaruh signifikan positif terhadap kualitas laporan keuangan pemerintah daerah sedangkan kompetensi sumber daya manusia tidak berpengaruh secara signifikan terhadap kualitas LKPD.

\section{Saran}

Berdasarkan hasil analisis data dan pembahasan yang telah disajikan sebelumnya, maka dapat diberikan saran sebagai berikut :

1. Penelitian ini dapat memberikan implikasi penting bagi Organisasi Perangkat Daerah untuk mempertimbangkan persyaratan perekrutan sumber daya manusia pada Sub. Bagian Perencanaan dan Keuangaan, Memberikan pelatihan khusus untuk menunjang kualitas kinerja pegawai dan pemberian reward kepada pegawai yang berprestasi sebagai bentuk apresisasi

2. Bagi Perangkat Daerah Kota Malang hasil penelitian ini dapat digunakan sebagai salah satu inputan untuk dapat memenuhi persyaratan kompetensi pada posisi yang bertugas membantu dan mendukung penyajian kualitas laporan keuangan pemerintah daerah, mengingat hasil uji atas variabel ini menurut responden dianggap tidak memepengaruhi kualitas laporan tersebut, kondisi ini bertolak belakang dengan persyaratan jabatan yang telah ditetapkan dalam analisa jabatan jabatan dan analisa beban kerja untuk staf yang ada pada Sub. Bag Perencanaan dan Keuangan

3. Bagi Universitas Kanjuruhan Malang penelitian ini dapat memberikan kontribusi dan menambah referensi yang berkaitan dengan laporan keuangan sektor publik.

4. Bagi peneliti selanjutnya agar dapat menggunakan pendekatan penelitian yang berbeda atau menambahkan variabel lain yang dapat mempengaruhi kualitas laporan keuangan pemerintah daerah.

\section{DAFTAR PUSTAKA}

A.A Anwar Prabu Mangkunegara (2012). Manajemen Sumber Daya Manusia. Bandung: PT. Remaja Rosdakarya.

Anggreni, Ni Made Mei; Widanaputra, A.A.G.P.; Putri, IG.A.M. Asri Dwija. (2018). Pengaruh Good Governance dan Kompetensi Sumber Daya Manusia pada Kualitas Laporan Keuangan di Kota Denpasar. (https://ojs.unud.ac.id/index.php/Akuntansi/article/view/35821), Diakses 01 November 2019.

Ghozali, Imam. (2016). Aplikasi Analisis Multivariete Dengan Program IBM SPSS 25. Semarang : Badan Penerbit Universitas Diponegoro. 
Vika Erinna AgustiningTyas, Pengaruh Good Governance, Sistem Pengendalian Intern Pemerintah, Kompetensi Sumber Daya Manusia Terhadap Kualitas Laporan Keuangan Pemerintah Daerah (LKPD)

Pada OPD Kota Malang

JawaPos.com. (2018, September 28). 42 Anggota DPRD Korupsi, Kota Malang Tetap Raih WTP dari Kemenkeu. (https://www.jawapos.com/jpg-today/28/09/2018/42-anggota-dprd-korupsikota-malang-tetap-raih-wtp-dari-kemenkeu/), Diakses 03 November 2019

MalangTimes.com (2019, Juli 19). Brexit, Bawa Kota Malang Raih Top 99 Inovasi Pelayanan Publik 2019. (https://www.malangtimes.com/baca/41809/20190719/181200/brexit-bawa-kota-malangraih-top-99-inovasi-pelayanan-publik-2019), Diakses 03 November 2019

Merdeka.com. (2019, Oktober 07). Kota Malang Kali Ke-8 Raih WTP. (https://malang.merdeka.com/kabar-malang/kota-malang-kali-ke-8-raih-wtp191007w.html), Diakses 03 November 2019

Mahmudi. (2019). Analisis Laporan Keuangan Pemerintah Daerah Edisi Keempat. Yogyakarta: UPP STIM YKPN.

Nordiawan, Deddi; Hertianti, Ayuningtyas. (2010). Akuntansi Sektor Publik Edisi 2. Jakarta: Salemba Empat.

Peraturan Pemerintah No. 18 Tahun 2016 Tentang Perangkat Daerah. (https://www.bkn.go.id/wpcontent/uploads/2016/10/PP-NOMOR-18-TAHUN-2016-PERANGKAT-DAERAH.pdf), Diakses 29 Oktober 2019.

Peraturan Pemerintah Republik Indonesia Nomor 60 Tahun 2008 Tentang Sistem Pengendalian Intern Pemerintah.

(http://www.bpkp.go.id/public/upload/unit/sakd/files/PP60Tahun2008 SPIP.pdf)

Diakses pada 30 Oktober 2019.

Peraturan Pemerintah Republik Indonesia Nomor 71 Tahun 2010 Tentang Standar Akuntansi Pemerintahan. (2012). Jakarta: Salemba Empat.

Priansa, Donni Juni. (2018). Manajemen Organisasi Publik Mengembangkan Organisasi Modern Berorientasi Publik. Bandung: CV Pustaka Setia.

Ramadhani, Abdul Aziiz. (2018). Pengaruh Kompetensi Sumber Daya Manusia, Penerapan Sistem Akuntansi Keuangan Daerah (SAKD), Pemanfaatan Teknologi Informasi, Sistem Pengendalian Intern Dan Kompetensi Staf Terhadap Kualitas Laporan Keuangan Pemerintah Daerah Kota Surakarta. (http://eprints.ums.ac.id/62103/1/NASKAH\%20PUBLIKASI.pdf), Diakses 01 November 2019.

Rusvianto, Dimas. Mulyani, Sri \& Yuliafitri,Indri. (2018). Pengaruh Pelaksanaan Sistem Pengendalian Internal Pemerintah Daerah (Studi Empiris pada SKPD Kota Bandung). (http:/jurnal.uinbanten.ac.id/index.php/bs/article/view/1070 Jurnal BanqueSyar'i Vol. 4 No. 1 Januari-Juni 2018), Diakses 29 Oktober 2019.

Sari, Gusrya Indria; Fadli. (2016). Pengaruh Penerapan Good Governance, Standar Akuntansi Pemerintahan, Dan Pemanfaatan Sistem Informasi Akuntansi Keuangan Daerah Terhadap Kualitas Laporan Keuangan Daerah Provinsi Bengkulu.(http://repository.unib.ac.id/14047/), Diakses 01 November 2019.

Sutrisno, Edy. (2010). Manajemen Sumber Daya Manusia. Jakarta: Kencana. 
Vika Erinna AgustiningTyas, Pengaruh Good Governance, Sistem Pengendalian Intern Pemerintah, Kompetensi Sumber Daya Manusia Terhadap Kualitas Laporan Keuangan Pemerintah Daerah (LKPD)

Pada OPD Kota Malang

Wijayanti, Lilis. (2017). Pengaruh Kompetensi Sumber Daya Manusia, Sistem Pengendalian Intern, Dan Teknologi Informasi Terhadap Kualitas Laporan Keuangan Pemerintah Daerah. (http://eprints.ums.ac.id/49380/), Diakses 30 Oktober 2019 